\title{
Afebrile Kawasaki Disease Presenting as Intestinal Pseudo-Obstruction
}

\author{
Yu Wen, ${ }^{1}$ Ying Chen, ${ }^{1}$ Huiling Lu, ${ }^{1}$ and Xiufen $\mathrm{Hu}^{1,}{ }^{,}$ \\ ${ }^{1}$ Department of Pediatrics, Tongji Hospital Affiliated to Tongji Medical College, Huazhong University of Science and Technology, Wuhan, China \\ "Corresponding author: Xiufen Hu, Department of Pediatrics, Tongji Hospital Affiliated to Tongji Medical College, Huazhong University of Science and Technology, Wuhan \\ 430030, China, E-mail: xfhu2007@163.com \\ Received 2018 March 11; Revised 2018 May 14; Accepted 2018 May 15.
}

Keywords: Kawasaki Disease, Afebrile, Intestinal Pseudo-Obstruction

\section{Dear Editor,}

Thank you for providing us an opportunity to report a case of rare atypical Kawasaki disease (KD). As we know, KD is an acute febrile illness of childhood associated with vasculitis of medium-sized arteries, especially the coronary arteries. Through this letter, we would like to share our experience managing the case of a 7-month-old boy suffering from a rare atypical $\mathrm{KD}$, which presented as intestinal pseudo-obstruction without fever. To our knowledge, no such case has ever been reported before. We believe that the awareness about such clinical presentation is critically important as it may otherwise lead to delayed diagnosis and therapy, subsequently may worsen the prognosis.

Kawasaki disease is an acute, self-limited systemic type of vasculitis that occurs predominantly in young children and results in 20 - 25\% of coronary artery abnormalities (CAA) in untreated children (1). Treatment with intravenous immunoglobulin (IVIG) in combination with acetyl salicylic acid (ASA) before the 10th day of illness reduces the prevalence of CAA to 3 - 5\% (2). Therefore, timely diagnosis and treatment are essential to prevent CAA. The diagnosis is based on clinical criteria and non-specific laboratory findings. Fever is the most critical symptom in KD. Fever prolongation ( $\geq 5$ days) is a necessary diagnostic criterion established by the American heart association (AHA) (1), that is different from the Japanese guidelines (3) in which fever prolongation is just an optional criterion. To increase the awareness of afebrile $\mathrm{KD}$, we report a 7-monthold boy who presented with intestinal pseudo-obstruction without fever and was subsequently diagnosed with KD.

A 7-month-old male child was brought to the emergency of his local pediatric clinic with the chief complaints of abdominal distension, constipation, crying and skin erythema for one day along with reduced appetite. There was no fever, vomiting, cheilitis or conjunctival erythema. The white blood cell count (WBC) was $21.78 \times 10^{9} / \mathrm{L}$, Neu
81.7\%, hemoglobin ( $\mathrm{Hb}) 92 \mathrm{~g} / \mathrm{L}$, platelet count (PLT) $464 \times$ $10^{9} / \mathrm{L}$. The erect abdominal radiograph was suggestive of intestinal obstruction (Figure 1). The child was therefore given glycerine enema. However, after defecation, he was still irritable. He was transferred to our hospital and was admitted to the ward. On physical examination, there was erythema on the trunk. Desquamations over the left thumb and around anus were noted. The abdomen was still distended, and the rumbling sound of the abdomen was weak. The axillary temperature was $36.8^{\circ} \mathrm{C}$, and he had never suffered from fever during the past two weeks.

On the day of admission, the blood routine showed leukocytosis with WBC $29.64 \times 10^{9} / \mathrm{L}$, Neu 78.7\%, Hb $94 \mathrm{~g} / \mathrm{L}$ and PLT $636 \times 10^{9} /$ L. Erythrocyte sedimentation rate (ESR) was $67 \mathrm{~mm} / \mathrm{h}$ and C-reactive protein (CRP) level was 62.9 $\mathrm{mg} / \mathrm{L}$. Urinalysis and electrocardiogram (ECG) were normal. Although he did not have a fever, incomplete KD was suspected. Ultrasonic cardiogram (UCG) performed on the second day after admission revealed dilatation of right coronary artery (RCA) with a diameter of $2.5 \mathrm{~mm}$ and $2.3 \mathrm{~mm}$ in diameter at the left main coronary artery (LCA), while aortic annular diameter was $12 \mathrm{~mm}$. This patient was diagnosed as having incomplete KD and then received intravenous immunoglobulin (IVIG) $2 \mathrm{~g} / \mathrm{kg}$ in combination with middle dose oral aspirin $(30 \mathrm{mg} / \mathrm{kg} / \mathrm{d}$ ). On the 4 th day of therapy, his irritability was resolved and rash faded. On the 7th day of treatment, he was discharged from the hospital with a normal CRP level $(2.32 \mathrm{mg} / \mathrm{L})$. The other hematological studies included WBC $8.06 \times 10^{9} / \mathrm{L}$, Neu $32.4 \%, \mathrm{Hb}$ $87 \mathrm{~g} / \mathrm{L}$, PLT $397 \times 10^{9} / \mathrm{L}$ and ESR $49 \mathrm{~mm} / \mathrm{h}$. We subsequently started long-term anticoagulation with low-dose aspirin and dipyridamole. Serial echocardiograms demonstrated normalization of his coronary system (RCA diameter, 1.8 $\mathrm{mm}$; LCA diameter, $1.9 \mathrm{~mm}$ ).

$\mathrm{KD}$ is one of the most common vasculitides in childhood. The diagnosis is based on clinical criteria and non- 


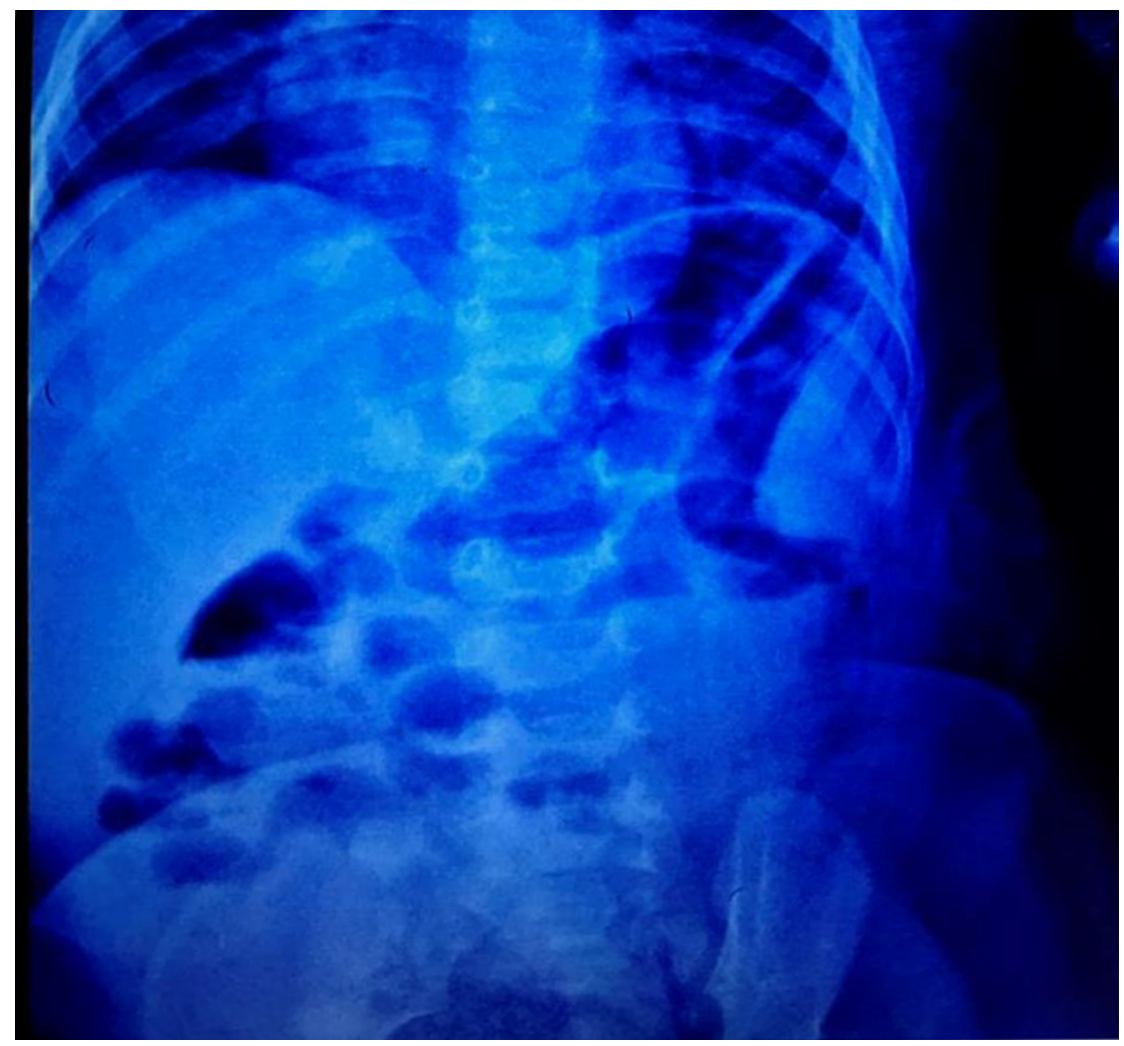

Figure 1. Air fluid levels on the erect abdominal X-ray suggestive of intestinal obstruction

specific laboratory findings (1). These clinical features can vary and manifest sequentially which makes the diagnosis difficult at one point of the presentation. Incomplete $\mathrm{KD}$ (fewer than four clinical features) has been reported to be an essential cause of delayed diagnosis, and it is also at high risk of CAA (1) Among the infantile KD, approximately $35 \%$ belong to incomplete form, thereby resulting in much higher chance of delayed clinical recognition and treatment in this group of patients (4). Consequently, coronary artery lesions (including an aneurysm) were developed in $85 \%$ of infants younger than six months with incomplete $\mathrm{KD}$ (5). In particular, afebrile incomplete KD is most likely to be delayed for the diagnosis, potentially worsening prognosis. During the past ten years, only 7 cases of afebrile Kawasaki disease were reported (Table 1) (6-9). These patients presented with conjunctival congestion in 7 (100\%), mucosal changes in five (71\%), rash in four (57\%), extremity changes in four (57\%), cervical lymphadenopathy in two (28\%), and bacille Calmette-Guerin scar reactivation in two (28\%) cases. Coronary artery abnormalities were present in five (71\%) patients. Such higher risk of coronary abnormalities was attributed to delayed diagno- sis and therapy since all the patients were diagnosed beyond ten days of illness.

In our case, the patient met two manifestations of KD which were polymorphous exanthema and changes in the extremities without fever and others. Besides afebrile feature, our case is also characterized by intestinal pseudo-obstruction. To our knowledge, intestinal pseudoobstruction has rarely been described at the onset of KD before the development of typical manifestations, especially fever. The pathogenesis of intestinal pseudo-obstruction is probably due to focal vascular insufficiency which is related to mesenteric artery vasculitis with bowel ischemia and myenteric plexus dysfunction. Its occurrence varies from $1.4 \%$ to $2.6 \%$ of children with $\mathrm{KD}(10)$. In this paper, we highlight the presence of intestinal pseudo-obstruction with an unexplained inflammatory response which may provide an important diagnostic basis for afebrile KD.

In conclusion, the clinical manifestations in this patient arouse the attention of clinicians that the unexplained inflammation of intestinal pseudo-obstruction can be the onset of atypical KD even in the absence of fever. Careful physical examination and echocardiogra- 


\begin{tabular}{|c|c|c|c|c|c|c|}
\hline Case & Author & Age/Gender & Typical Manifestations & $\begin{array}{l}\text { Laboratory } \\
\text { Abnormalities }\end{array}$ & Echocardiogram & Treatment \\
\hline $\mathbf{1}$ & $\begin{array}{l}\text { Saltigeral-Simental et } \\
\text { al.(6) }\end{array}$ & 3 years $/ \mathrm{F}$ & $\begin{array}{l}\text { Maculopapular rash, } \\
\text { periungual desquamation, } \\
\text { erythematous lips, aseptic } \\
\text { conjunctivitis. }\end{array}$ & $\begin{array}{l}\text { WBC12.1 } \times 10^{9} / \mathrm{L}, \text { ESR13 } \\
\mathrm{mm} / \mathrm{h} .\end{array}$ & $\begin{array}{l}\text { Dilatation of } \\
\text { coronary artery }\end{array}$ & $\begin{array}{l}\text { IVIG } 2 \mathrm{~g} / \mathrm{kg} \text { for } 3 \\
\text { times, aspirin }\end{array}$ \\
\hline 3 & Kato $T$ et al. (6) & 2 years/M & $\begin{array}{l}\text { Conjunctival injection, } \\
\text { desquamation, arthralgia. }\end{array}$ & $\begin{array}{l}\text { WBC11.5 } \times 10^{9} / \mathrm{L}, \mathrm{CRP} 41 \\
\mathrm{mg} / \mathrm{L} .\end{array}$ & $\begin{array}{l}\text { Coronary arterial } \\
\text { ectasia in segments } 1 \text {, } \\
5 \text {, and } 6 \text { with } \\
\text { pericardial effusion }\end{array}$ & Aspirin \\
\hline 5 & $\begin{array}{l}\text { Gonca Keskindemirci } \\
\text { et al.(8) }\end{array}$ & 17 months/M & $\begin{array}{l}\text { Conjunctival injection, } \\
\text { edema of his hands, } \\
\text { erythematous lips, } \\
\text { desquamation. skin } \\
\text { erythema, }\end{array}$ & $\begin{array}{l}\text { WBC15.7 } \times 10^{9} / \mathrm{L}, \text { PLT } 419 \times \\
10^{9} / \mathrm{L}, \text { ESR75 mm/h, CRP5 } 4 \\
\text { mg/L. }\end{array}$ & Normal & $\begin{array}{l}\text { IVIG } 2 \mathrm{~g} / \mathrm{kg} \text { for, } 1 \text { time, } \\
\text { aspirin }\end{array}$ \\
\hline 6 & Yoshino A e t al. (9) & 7 months/F & $\begin{array}{l}\text { Conjunctival injection, } \\
\text { redness around a bacillus } \\
\text { Calmette-Guerin (BCG) } \\
\text { inoculation site. }\end{array}$ & $\begin{array}{l}\text { WBC14.3 } \times 10^{9} / \mathrm{L}, \text { PLT } 949 \\
\times 10^{9} / \mathrm{L}, \text { ESR } 125 \mathrm{~mm} / \mathrm{h}, \text { CRP } \\
94.3 \mathrm{mg} / \mathrm{L} .\end{array}$ & $\begin{array}{l}\text { Bilateral CA } \\
\text { dilatations: RCA } 3.9 \\
\text { mm and LCA } 4.3 \mathrm{~mm} \\
\text { in diameter }\end{array}$ & $\begin{array}{l}\text { IVIG } 2 \mathrm{~g} / \mathrm{kg} \text { for } 1 \text { time, } \\
\text { aspirin }\end{array}$ \\
\hline 7 & Yoshino A e t al. (9) & 13 months/M & $\begin{array}{l}\text { Conjunctival injection and } \\
\text { redness around a BCG } \\
\text { inoculation site, slight } \\
\text { redness of his lips and } \\
\text { hands. }\end{array}$ & $\begin{array}{l}\text { WBC18.9 } \times 10^{9} / \mathrm{L}, \text { PLT } 450 \\
\times 10^{9} / \mathrm{L}, \mathrm{CRP} 7.5 \mathrm{mg} / \mathrm{L} .\end{array}$ & $\begin{array}{l}\text { Normal CA and a } \\
\text { small pericardial } \\
\text { effusion. The second } \\
\text { UCG ( bilateral CA } \\
\text { dilatations: RCA } 3.8 \\
\text { mm in diameter and } \\
\text { LCA } 4.5 \mathrm{~mm} \text { )., }\end{array}$ & Aspirin, cyclosporin \\
\hline
\end{tabular}

Abbreviations: CA, coronary artery; LCA, left coronary artery; RCA, right coronary artery.

phy should be considered for assessment of potential cardiovascular lesions for early diagnosis and treatment, and thus minimizing the complications of KD.

\section{Footnote}

Funding/Support: This report was supported by grants from national natural science foundation of China (\#30800385 to Yu Wen).

\section{References}

1. McCrindle BW, Rowley AH, Newburger JW, Burns JC, Bolger AF, Gewitz M, et al. Diagnosis, Treatment, and Long-Term Management of Kawasaki Disease: A Scientific Statement for Health Professionals From the American Heart Association. Circulation. 2017;135(17):e92799. doi: 10.1161/CIR.0000000000000484. [PubMed: 28356445].

2. Patel RM, Shulman ST. Kawasaki disease: a comprehensive review of treatment options. J Clin Pharm Ther. 2015;40(6):620-5. doi: 10.1111/jcpt.12334. [PubMed: 26547265].
3. Ayusawa M, Sonobe T, Uemura S, Ogawa S, Nakamura Y, Kiyosawa $\mathrm{N}$, et al. Revision of diagnostic guidelines for Kawasaki disease (the 5th revised edition). Pediatr Int. 2005;47(2):232-4. doi: 10.1111/j.1442200x.2005.02033.x. [PubMed: 15771703].

4. Singh S, Agarwal S, Bhattad S, Gupta A, Suri D, Rawat A, et al. Kawasaki disease in infants below 6 months: a clinical conundrum? Int J Rheum Dis. 2016;19(9):924-8. doi: 10.1111/1756-185X.12854. [PubMed: 26990891].

5. Genizi J, Miron D, Spiegel R, Fink D, Horowitz Y. Kawasaki disease in very young infants: high prevalence of atypical presentation and coronary arteritis. Clin Pediatr (Phila). 2003;42(3):263-7. doi: 10.1177/000992280304200310. [PubMed: 12739925].

6. Rodriguez-Lozano AL, Rivas-Larrauri FE, Hernandez-Bautista VM, Yamazaki-Nakashimada MA. Fever is not always present in Kawasaki disease. Rheumatol Int. 2011;32(9):2953-4. doi: 10.1007/s00296-011-21234.

7. Ulloa-Gutierrez R, Perez A, Gutierrez-Alvarez R. Kawasaki disease without fever in a Costa Rican girl: first report from Central America. Rheumatol Int. 2013;33(12):3097-8. doi: 10.1007/s00296-012-2563-5. [PubMed: 23124733].

8. Keskindemirci G, Ayaz NA, Aldemir E, Akcay A, Oztarhan K, Aydogan G. A case of incomplete Kawasaki disease without fever. Ann Paediatr Rheumatol. 2013;2(2):89-90. 
9. Yoshino A, Tanaka R, Takano T, Oishi T. Afebrile Kawasaki disease with coronary artery dilatation. Pediatr Int. 2017;59(3):375-7. doi: 10.1111/ped.13214.

10. Trapani S, Montemaggi A, Simonini G, Calabri GB, Messineo A, Resti M.
Surgical abdomen with intestinal pseudo-obstruction as presenting feature of atypical Kawasaki disease. J Paediatr Child Health. 2016. doi: 10.1111/jpc.13284. [PubMed: 27654849]. 